\title{
Engaged Scholarship: How to Improve University Engagement within Academic-Industry Relationships
}

Conor Horan

Technological University Dublin, conor.horan@tudublin.ie

Follow this and additional works at: https://arrow.tudublin.ie/buschmarcon

Part of the Business Commons

\section{Recommended Citation}

Horan, C. (2021). Engaged Scholarship: How to Improve University Engagement within Academic-Industry Relationships. 21st European Conference on Knowledge Management, Coventry, Sep 3, 2020 - Sep 4, 2020. doi:10.34190/EKM.20.108

This Conference Paper is brought to you for free and open access by the School of Marketing at ARROW@TU Dublin. It has been accepted for inclusion in Conference papers by an authorized administrator of ARROW@TU Dublin. For more information, please contact arrow.admin@tudublin.ie, aisling.coyne@tudublin.ie, gerard.connolly@tudublin.ie.

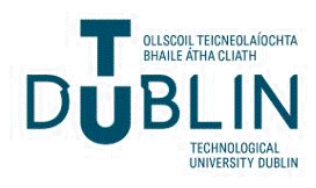


See discussions, stats, and author profiles for this publication at: https://www.researchgate.net/publication/346628766

\section{Engaged Scholarship: How to Improve University Engagement within Academic-Industry Relationships}

Conference Paper · December 2020

DOI: 10.34190/EKM.20.108

CITATIONS

0

1 author:

Conor Horan

Technological University Dublin - City Campus

36 PUBLICATIONS 212 CITATIONS

SEE PROFILE

Some of the authors of this publication are also working on these related projects:

Project A Processual Understanding of "Knowledge Creating" View project

Project Research Methods Pedagogy View project
READS

73 


\title{
Engaged Scholarship: How to Improve University Engagement within Academic-Industry Relationships
}

\author{
Conor Horan and Nkechinyem Omeife \\ School of Marketing, Technological University Dublin, Ireland \\ conor.horan@TUDublin.ie \\ omeife.nkechinyem@TUDublin.ie \\ DOI: 10.34190/EKM.20.108
}

\begin{abstract}
Since the notion of engaged scholarship was articulated and debated (Van de Ven, 2007, McKelvey, 2006, Van De Ven and Johnson, 2006b, Van De Ven and Johnson, 2006a) it has received increased scholarly attention, informed debates questioning the role of the university in society, and how universities produce relevant knowledge for and with society. While questions are raised about how an engaged scholarship lens might meaningfully improve academic-industry relationships, less attention has focused on the characteristics of engagement that can illustrate why one form of relationship in practice is more "engaged" compared to another. The engaged scholarship lens distances itself from efforts to theorise a knowledge transfer solution to narrowing conceptualised divides between academic and industry. Using this distinction as a foundation for characterising how we might improve such relationships, this paper compares and contrasts different solutions to better explore how knowledge is disseminated within and across academic-industry boundaries. To do so we draw upon knowledge transfer literature and relationship marketing's understanding of inter-organisational relationships. We further explore the implications this approach might have for the role of the university and its ability to produce knowledge for and with society (Gibbons et al 1994). We draw upon the activities of the newly formed Technological University of Dublin (TU Dublin) as it attempts to position itself as a truly "engaged university". The challenges in restructuring and repositioning TU Dublin to achieve this status focuses on its support for engaged research, community engagement and widening participation activities within the context of its organisational redesign initiative (2019-2022). This paper concludes by providing insights into how we can improve meaningful engagement. The implications of a transfer solution to academic-industry relationships for redesign is compared to a solution based on engaged scholarship. How either solution draws on aspects of knowledge management is discussed. We advocate for a deeper understanding of knowledge management based on engaged scholarship principles and illustrate how it differs from a knowledge management perspective based on assumptions of transfer in a context of organisational redesign.
\end{abstract}

Keywords: Engaged Scholarship, Knowledge Transfer, Organisational Design

\section{Introduction}

The characteristics of different academic-industry relationships have received varying degrees of attention in the literature. However discussions have been predominantly characterised by two main assumptions. Firstly, the academic-industry relationship suffers from a theory versus practice divide problem. Secondly, efforts to solve this the theory-practice divide problem has been characterising as a problem of knowledge transfer. As the skills and instruments of science becomes more distributed and accessible, industry and society at large have begun to play a greater role in knowledge production. In this evolving landscape scholars have raised questions about the traditional role of universities as society's dominant knowledge producers (Gibbons et al., 1994). Similarly, questions have be asked about the impact of scholarly activities within the context of divided relationships between academia and industry (Nowotny et al., 2001). To address this change Van de Ven \& Johnson (2006a) claim that attempts to improve academic-industry relationships by relying on improving knowledge transfer is a failed solution.

To achieve a status of a truly "engaged university" might require a fundamental rethink about the role and activities of a university in society. By embracing an engaged scholarship approach there are implications for how we evaluated different types of academic-industry relationships as being impactful. To better improve ongoing engagement activities it may well require significant organisational redesign initiatives. We draw upon the activities of the newly formed Technological University of Dublin (TU Dublin) as it attempts to position itself as a truly "engaged university". The challenges it faces in restructuring and repositioning itself as a technological university close to society is no mean feat. To achieve this status TU Dublin is attempting to focuses on issues of engaged research, community engagement and widening participation activities. But questions about the types of relationships TU Dublin should foster, as well as the management of the dynamics within those relationships, provide a rationale for comparing the transfer agenda with the ideas associated with engaged scholarship. By illustrating the differences between knowledge management based on transfer assumption and knowledge based on engaged scholarship assumptions, we aim to inform TU Dublin's ongoing organisational 
redesign initiative (2019-2022) with practical recommendations. We turn now to describe academic-industry relationships from a transfer perspective. Modal theory of knowledge production is introduced to reflect the changing role of the university. The following section explores an engaged scholarship perspective. We finally address some organisational redesign implications for a new technological university.

\section{Knowledge Transfer Approaches to Academic-Industry Relationships}

Research on the dynamics of academic-industry relationships has tended to focus on the importance of narrowing the theory-practice divide and/or the perceived gaps between academics and practitioners as a problem of knowledge transfer or translation. Empirical research on academic-industry knowledge transfer has tended to focus either on firm or university characteristics. While the research agendas for firms and universities are similar they reflect different perceived research problems (Agrawal, 2001).

Firstly research on firms focuses on improving knowledge transfer by improving engagement with universities or available research that can found in the public domain. Research questions relating to how efficiently firm's take advantage of geographically placed knowledge spillovers, their connectivity to universities and their ability to absorb new knowledge is argued as contributing to their 'absorptive capacity' (Cohen and Levinthal, 1989, Cohen and Levinthal, 1990, Easterby-Smith et al., 2008, Lim, 2009). How firms allocate resources to invest in and facilitate their ability to absorb, or the ability to transfer knowledge across the firms boundary represents the main focus here (Agrawal, 2002, Van den Bulte et al., 2001, Nieto and Quevedo, 2005). One important activity, for example, is how firms actively engage in developing their own research patents as a factor influencing their absorptive capacity (Agrawal and Henderson, 2002). By improving this it is argued they can increase their ability to engage in joint research projects, with universities for example, and take advantage of the knowledge spillovers by transferring and incorporating them into their own activities (Cockburn and Henderson, 1998, Cohen and Levinthal, 1990, Cohen and Levinthal, 1989). An extension of this line of thinking has developed around identifying and reducing knowledge barriers in the field of knowledge management.

Secondly, research focused on university activities, on the other hand, is preoccupied with improving outward transfer of knowledge to industry and society by narrow various divides. To narrow the theory-practice divide it is important that the transfer of knowledge is improved at this inter-organisational level of analysis (Agrawal, 2001). For example, the number and commercialisation of patents is used as a metric for measuring the success of university knowledge transfer activities as one transfer channel (Agrawal, 2001, Agrawal and Henderson, 2002). Other channels include metrics relating to the supports for entrepreneurs in incubation centres (Agrawal and Henderson, 2002), accelerators (Chedid et al., 2020, Hallen et al., 2020), the importance of joint R\&D projects to produce public knowledge (Barnes et al., 2002, Cohen and Levinthal, 1989, Fernández-López et al., 2020) as well as technology transfer (Perkmann et al., 2013).

The improve of knowledge transfer at the academic-practitioner level of relationships (Rynes et al., 2001) a number of an additional channels have been identified. Hughes et al (2011) outline various options such as; providing courses and programmes as a teaching, learning and pedagogic channel; the publication of research at conferences and in peer review journals; the creation of knowledge networks as a channels and academic consultancy. They argue here that narrowing the divide or reducing the gap is a matter of improving how 'close' academics can get to the reality of business on a practical level as a means to transfer knowledge to practitioners. Transactive approaches to transfer have been identified as contributing to distant "arms-length" relationships (Perkmann and Walsh, 2007).

Similarly university policy decisions relating to research funding and the role of the university in transfer relationships have predominantly focuses on either / or oppositional decisions as tensional dualisms. For example to improve transfer, and narrow perceived divides, should research funding be directed to support pure research with no clear application or return on investment or applied research with potential opportunities for commercialisation and application? Should theory versus practice based activities, which have the potential to be more revenue bearing, be prioritised by the university? Should uncertain, and expensive exploration activities be supported instead of exploitation activities? By pursuing a relevant, applied and exploitation strategy will it undermine academic rigour and reduce the quality of knowledge produced (Gibbons et al., 1994 p.8,31-32,152154)? Agrawal (2001) notes that the assumptions underpinning these decisions and identified channels, is that knowledge transfer remains the responsibility of the university. This arguably reflects an additional but questionable assumption - that the university remains the centre of knowledge production in society in what is 
termed as a Mode 1 form of knowledge production (Gibbons et al., 1994). Combined these assumptions perpetuate a strategic focus of knowledge transfer as the way to narrow singular channels divides to 'solve' and eliminate oppositional tensions within decision making, without considering wider multi-faceted links within and across university-industry relationships. They argue that the need to take a multi-faceted approach to how the organisation and management of university-industry collaboration is required to better inform the activities, policies and improve the role of universities in society (Perkmann and Walsh, 2007 p.262). We turn now to consider the questionable assumption that universities are the primary source of knowledge production in society and indicate how this might alter the hegemonic view that narrowing academic-industry divides remains a problem of knowledge transfer.

\section{The Changed Role of the University in Society}

At the societal level of analysis the modal theory of knowledge (Gibbons et al., 1994) prompted much discussion about the changed role of the university in society. If the university is no longer society's primary source of knowledge production, what does it mean for the knowledge transfer solution to narrowing the divides separate the university from society? In addition, how might this prompt university officials to revise and reconceptualise their understandings of broader academic-industry relationships?

The first approach was to overcome the double or dual hurdles of rigour and relevance (Pettigrew, 1997). However this arguably presented more criteria to be met by industry for successful transfer. Whereas it advocated for a policy that pursued the relevance of university research to industry and society it also assumed academic rigour in a normative academic sense was the desired level of rigour. What Pettigrew did achieve however was that it started similar attempts to address oppositional and tensional dualisms, such as rigour versus relevance, to bridge other perceived divides. Similarly successful knowledge production in society was seen as being a function of the relationship between theory and practice (Nowotny et al., 2001, Van De Ven and Johnson, 2006a). Continued knowledge production would be dependent on combining the two within and across the academic-industry context. This discussion contributed to the second more dominant approach to overcome the dual hurdles of rigour versus relevance through the application of a Mode 2 perspective of knowledge production.

By way of summary a Mode 1 form of knowledge production assumed that knowledge was to be produced in the university and then transferred to industry or society. Here the legitimacy of knowledge of knowledge could be controlled before uni-directional events of transfer, as problems are set and solved under academic governance without consideration for wider non-academic perspectives from societal stakeholders. Knowledge production was thus produced within agreed academic silos in a manner removed and isolated from users of such knowledge (Gibbons et al., 1994 p.3). The Mode 2 approach promised a more accurate description of how knowledge was being produced in society. It argued that due to the massification of scientific education knowledge was now being produced increasingly being produced in practice of a context of application (pp.3-4) allowing for the inclusion of diverse stakeholders in the research process and aided by increased opportunities for transdisciplinary research (pp.4-6). They claim that "working in the context of application increases the sensitivity of scientists and technologists to the broader implication of what they are doing" (p.7) and raises more complex questions about socially acceptable research questions and the quality of the knowledge that is produced. What becomes acceptable knowledge is therefore broadened to "incorporate a diverse range of intellectual interests as well as social, economic and political ones" (p.8). In a Mode 2 context creating and maintain the density of relationships between science and society becomes a focal aspect of university strategy. This description of academic-industry relationships challenges universities, whose privileged positions around the control, production and transfer of knowledge is being eroded, to reassess their strategic role and agenda (Huff, 2000, Huff and Huff, 2001). Huff acknowledged that Mode 1 knowledge production won't disappear and claimed that business schools held a unique position and competitive advantage in being able to take advantage of both Mode 1 and Mode 2 within a Mode 1.5 space (Huff, 2000). In this way the ideas in university contexts such as business schools could be used to increase the relevance of the academy and its research (Hambrick, 1994, Bennis and O'Toole, 2005, Starkey and Madan, 2001). By advocating Mode 2 the authors ask what are "the key issues that need to be considered in the discussion of relevance and knowledge creation" (Starkey, 2001 p.S4) and/or what impact has research from business schools had (Starkey, 2001 p.S78)? In difficult recessionary times, such as the financial crisis from 2008 and the pandemic crisis in 2020, with increased social and financial accountability, the need for relevance is more pressing than ever requiring knowledge not just to be merely transferred but to be produced alongside various stakeholders i.e. medical, public health pharmaceutical and 
society at large, in a context of application (Gibbons et al., 1994 pp.78-79). Only this would maintain the role of business schools as knowledge producers in society, narrowing the gap and aligning all stakeholders in research for knowledge production.

The implications of the modal theory of knowledge of knowledge production and early attempts to address and overcome the dual or double hurdle of management research (Pettigrew, 1997) was to call into question the hegemonic approach the narrowing of divides in singular academic-industry channels as a problem of mere transfer. In its place universities are encouraged to consider multifaceted academic-industry links (Perkmann and Walsh, 2007) and more collaborative approaches to produce relevant knowledge with various stakeholders in society. Only through close engagement, as opposed to arms-length transactional transfer, can knowledge be effectively developed and exchanged i.e. an engaged scholarship approach (Van De Ven and Johnson, 2006a). We now turn to discuss the lines of thinking that offer a way through with an emphasis on engaged scholarship.

\section{Engaged Scholarship Approaches to Academic-Industry Relationships}

By focusing on the nature of scholarship, and what it means to be a scholar, Boyer (1990) pointed to how universities prioritise research activities over teaching, and consequently reducing the diversity of academic goals across the US educational system and impairing the student experience. This refocused attention on the issue of faculty time, the activities of the professoriate and how this has changed overtime and the ramifications of this change for reward systems, student experience and the role of the university itself (Boyer 1990).

This comes at a time, he argued in the 1990's, when universities need to be even more connected and committed to the social and environmental challenges facing society. In his extensive historical review of the role of universities in the US (Boyer, 1990, 1996), Boyer showed how newly established academic institutions historically played a partnership role in addressing societal needs. But due to universities rewarding of pure research activities over applied work he argues that the commitment to this scholarship of engagement had dramatically declined (Boyer, 1996). To address he called for a renewed legitimacy around a broader more capacious meaning of scholarship that legitimatise all academic activities (Boyer, 1996). He advanced four areas that balanced the importance of teaching alongside research;

1. the scholarship of discovery which is akin to the doing of research;

2. the scholarship of integration which is associated with interpretation and the fitting of research into broader intellectual patterns;

3. the scholarship of the communal nature of sharing knowledge,

4. and the scholarship of application..

Building on this broader and more balanced focus of scholarship Van de Ven proposed a more expansive conceptualisation of engaged scholarship (Van de Ven, 2007). He argued that the difference between practical and scholarly knowledge within the rigour versus relevance debate has been misunderstood. In its place he suggests a process of engaged scholarship focusing on a strategy of arbitrage (Van de Ven, 2007). As noted at the beginning of this paper, engaged scholarship challenged the assumption and claim that "exhortations for academics to put their theories into practice and for managers to put their practices into theory may be misdirected because they assume that the relationship between knowledge of theory and knowledge of practice entails a literal transfer or translation of one into the other" (Van De Ven and Johnson, 2006a p.808). In response to criticisms of engaged scholarship (McKelvey, 2006) the authors further distanced themselves from the knowledge transfer agenda as a failed solution to narrowing the theory-practice divide (Van De Ven and Johnson, 2006 b) by arguing for a for a pluralistic and complementary view of knowledge from science and society. This they claim involves a negotiated collaborative process of knowledge co-production among academics and practitioners. Using the notion of intellectual arbitrage they say that it "represents a dialectical method of inquiry where understanding and synthesis of a common problem evolve from the confrontation of divergent theses and antitheses" (Van De Ven and Johnson, 2006a p.809). A strategy of arbitrage representing a pluralistic methodology acknowledges that a potentially problematic interpersonal aspect of arbitrage is the presence of conflict. But conflict represents the "generative mechanism of a dialectical process of inquiry" (p.809). By using this arbitrage and accepting generative tensions in dialogue they argue that the dual hurdles of rigour and relevance are surpassed and that the theory-practice divide is narrowed not by knowledge transfer alone but by engagement. This represented a shift away from focusing on dualisms to a focus on dualities as it supports the view that tension is generative as different views pertaining to the quality of knowledge is teased out through collaborative engagement. To tease this apart as number of characteristics become evident. 
The first is that an engaged strategy necessitates the inclusion of multiple stakeholders, as well as users of research at all stages of the research process. Starkey \& Madan developed this point further noting that through dialogue within in necessitate "joint development of a mutually beneficial research process" (2001 p.S4). By including additional stakeholders, including users of research, at various stages of the research process it allows the process to respond to their increasingly sophisticated demands (Starkey and Madan, 2001 p.S13 \& S18). Second, a principle of plurality also requires multiple methods of inquiry. Approaching scholarship in this manner ensures that different and varied research questions, that are more applicable to industry and society, are asked and addressed early in the collaborative process. Third, the inclusion of a plurality of stakeholders and methods, in the process from the start, reflects the inclusion of different views of 'relevance', which in turn improves the quality of relevant knowledge produced. By engaging with interdependent stakeholders valuable knowledge is brought to bear on different stages of the research process. Better research questions are formulated as relevance to industry is addressed from the start. This ensures that pure knowledge is constantly translated into applied knowledge throughout the process as opposed to the end of the process as an input for a commercialisation function or accelerator programme. Fourth, by placing emphasis on relevant knowledge the dual hurdles of rigour and relevance, as can be overcome. Similarly, if we include theory and practice within our decision making it should lead to more effective outcomes (Starkey and Madan, 2001 p.S6). By replacing established debates on dualisms e.g. pure versus applied research, rigour versus relevance, and theory versus practice; an engaged scholarship approach provides a way to circumvent discussions on conflicting dualisms and reconceptualise them as complementary dualities (Farjoun, 2010) in engaged practices (Feldman and Orlikowski, 2011). Truly engaged academic-industry processes rely on process of and its implications knowledge translation rather than mere transfer (Røvik, 2016), as well as true attempts to achieve knowledge integration (Grant, 1996). Fifth, due to the prevalence of debates that reflect tensions within academic-industry literature, the tendency to 'solve' such tensions is evident. However an engaged scholarship approach which is a truly pluralistic and assumes the importance of arbitrage shifts the emphasis away from finding a solution to one of accepting tensions as something to be bridged. Sixth, the relational aspects of engaged scholarship have been discuss in terms of how academics write and communicate with practitioner audiences. By emphasising Boyer's (1996) focus on knowledge integration across four key areas of discovery, integration, application and teaching, Bartunek emphasises the benefits of writing for wider audiences so as to break down boundaries and build mutually beneficial relationships i.e. relationship scholarship (Bartunek, 2007). However various bodies of literature can contribute to this issue;

1. Inter-Organisational Relationships and Relationship Marketing: approaches to understanding interorganisational have yet to be truly applied to academic-industry relationships. Literature on interorganisational relationships could also be applied here (McLoughlin and Horan, 2000, 2002) so as to that both parties are activities rather than Agrawal's depiction of passive employers waiting on universities to transfer knowledge (Agrawal, 2001) much like passive consumers who might react to business communications.

2. Knowledge Transfer Literature: Similarly a relationship view of scholarship might also draw on assumptions with knowledge management which emphasises similarly passive and unidirectional knowledge transfer (Paulin and Suneson, 2012, Kumar and Ganesh, 2009, Cross et al., 2001) would benefit from greater clarity (Easterby-Smith et al., 2008, Lane et al., 2006). Viewing university-industry relationships as inter-organisational relationships reflects an opportunity to apply the principles of relationship marketing literature to the academic-industry context. Similarly it provides an opportunity to reassess the knowledge transfer agenda in knowledge management (Hessels and Van Lente, 2008) in favour of approaches to knowledge exchange (Herschel et al., 2001), sharing (Wang and Noe, 2010, Casimir et al., 2012) and flows (Dahl and Pedersen, 2004).

3. Approaches to Dialogue: The role of research on dialogue has been widely recognised as important within the field of KM (Von Krogh et al., 2000). However it has rarely been applied to academic-industry contexts. Not only is the way in with academics communicate with practitioners (Bartunek, 2007) but also the dynamics of knowledge creation itself (Tsoukas, 2009) and the wicked problem of sciences' ability to communicate effectively with society (Oreskes, 2019).

Seventh, is that engaged scholarship and relational scholarship approaches emphasis actions as an impactful outcome. With a focus of inclusivity and relevance the goal of engagement to produce more meaningful knowledge that is actionable. What this means in practice is that for universities to be closer to industry and society it would require the allocation of resources specifically to facilitate engagement with multiple stakeholders. This may take the form of allowing academics the time to build meaningful links rather than engaged in enacting discrete transactions of transfer with industry. To achieve this as a strategic goal functional 
supports built into an organisational design might be appropriate beyond already established incubation centres or accelerators that arguably focus on the mere transfer of knowledge. This of course represents a long term strategic focus. If universities operate in a Mode 2 landscape it suggests that engagement, rather than isolation within that landscape is more important than ever. By calling into question the singular agenda of transfer and replacing it with a multifaceted engaged strategy it suggests that a scholarship of engagement is better laced to address a Mode 2 knowledge production landscape. The inclusion of centres that focus a multifaceted understanding of links might be required.

\section{Implications for an Organisational Re-Design of a New University}

This paper was written in the context of an organisational re-design in Ireland's first Technological University. By reviewing the available literature on university-industry relationships with a view to provide insight into the role of the university and academia to meet the ever changing and rapidly developing demands of industry ad society. The description of academia in its "ivory tower" removed from practices of the "real" world has long been levelled as a criticism of the university sector. Similarly calls to narrow the theory-practice divide, to be relevant in a world where knowledge is more dispersed than ever has presented significant challenges for policy makes and university officials.

If we review the role of the university through a Mode 1 lens of knowledge transfer, where dualisms are evident, and where the focus centres on the translation of academic knowledge into practice - the university involved in an organisational redesign runs a risk of privileging certain forms of codified explicit knowledge, that is readily communicated or transferred in discrete transactions to detached consumers of research. In contrast, if we view the role of the university through a Mode 2 lens of knowledge engagement, where different perspectives and their related tensions are embraced through a process of bridging divides rather than solving tensions - the university involved in an organisational redesign becomes more open to consider varied forms of relevant knowledge (both tacit and explicit), multiple approaches to maintain the quality of that knowledge, and relevant outcomes to a broader set of stakeholders. In this manner long-term relationships are fostered over short-term interactions. Through an engaged strategy the university has greater opportunities to respond in a timely fashion to the ever changing needs of industry and society. It can at the same time promote its central role, not in producing and transferring academic knowledge but in coordinating knowledge production in and with society.

If the mission of an new university is to be an engaged university or indeed an entrepreneurial university (Etzkowitz, 1998, Thijssen, 2009) limiting its practices, through its organisational deign to that of mere transfer will result in creating limited interactions with industry society. If the organisational design is solely to support transfer which is argued at best to be a limited or indeed a failed mechanism of engaging (Van De Ven and Johnson, 2006a) with society attempts to engagement more fully will become marginalised. An organisational design that considers the multifaceted links with industry and society has greater opportunities for producing relevant knowledge in the long term.

\section{Conclusion}

To support Boyer's four elements in an engaged manner might required additional supports allowing for discovery through initial engagement, integration through ongoing arbitration and translation, supports for the communal nature of sharing knowledge by making outputs digestible to multiple audiences, as well as supports for making relevant knowledge applicable to users of research. By including multiple stakeholders from the start an engaged entrepreneurial university might need to coordinate itself differently by developing a capability of engagement beyond its current commitment to incubation office and accelerators. The implications of this for an engaged university is that it allocates resource is not only to support pure research and teaching but to also support engagement and communication of that research to audiences in a collaborative forum. This shifts the role of the university away from a site of isolated production of pure knowledge to a site of embedded and engaged production of collaborative knowledge for multiple stakeholders.

The engaged entrepreneurial university should not only focus on producing products as outputs i.e. commercialisation and patents, but focus its attention on processes of coordination and facilitation along the path of inquiry. While much of the literature bestows a responsibility on the university to produce knowledge for a passive industry (Agrawal, 2001), an engaged strategy refocuses the university's role as the key site for discussion, discovery, integration sharing and application. The role of the university is not just about what it produces for society but how it facilitates knowledge production in society. By developing a capability of 
coordinating and facilitating engagement it can ensure its prominent and impactful role for knowledge production in society.

\section{References}

agrawal, A. 2001. University-to-industry Knowledge Transfer: Literature Review and Unanswered Questions. International Journal of Management Reviews, 3, 285.

Agrawal, A. 2002. Innovation, growth theory, and the role of knowledge spillovers. Innovation Analysis Bulletin, 4, 3-6.

Agrawal, A. \& Henderson, R. 2002. Putting Patents in Context: Exploring Knowledge Transfer from MIT. Management Science, 48, 44-60.

Barnes, T., Gibbons, A. \& Pashby, I. 2002. Effective University-Industry Interaction: A Multi-case Evaluation of Collaborative R\&D Projects. European Management Journal, 20, 272-285.

Bartunek, J. M. 2007. Academic-Practitioner Collaboration Need Not Require Joint or Relevant Research: Toward a Relational Scholarship of Integration. Academy of Management Journal, 50, 1323-1333.

Bennis, W. G. \& O'toole, J. 2005. How business schools lost their way. Harvard Business Review, 83, 96-104.

Boyer, E. L. 1990. Scholarship reconsidered: Priorities of the professoriate, ERIC.

Boyer, E. L. 1996. The scholarship of engagement. Bulletin of the American Academy of Arts and Sciences, 49, 18-33.

Casimir, G., LEE, K. \& LOON, M. 2012. Knowledge sharing: influences of trust, commitment and cost. Journal of Knowledge Management, 16, 740-753.

Chedid, M., Carvalho, T. \& TEIXEIRA, L. 2020. University-software industry collaboration: an empirical study based on knowledge management. Knowledge Management Research \& Practice, 1-13.

Cockburn, I. M. \& Henderson, R. M. 1998. Absorptive Capacity, Coauthoring Behavior, and the Organization of Research in Drug Discovery. Journal of Industrial Economics, 46, 157-182.

Cohen, W. M. \& Levinthal, D. A. 1989. Innovation and Learning: The Two Faces of R\&D. Economic Journal, 99, 569-596.

Cohen, W. M. \& Levinthal, D. A. 1990. Absorptive Capacity: A New Perspective on Learning and Innovation. Administrative Science Quarterly, 35, 128-152.

Cross, R., PARKER, A., Prusak, L. \& BORGATTI, S. P. 2001. Knowing What We Know: Supporting Knowledge Creation and Sharing in Social Networks. Organizational Dynamics, 30, 100-120.

Dahl, M. S. \& Pedersen, C. Ã. R. 2004. Knowledge flows through informal contacts in industrial clusters: myth or reality? Research Policy, 33, 1673-1686.

Easterby-SMITH, M., Graca, M., ANTONACOPOULOU, E. \& FERDINAND, J. 2008. Absorptive Capacity: A Process Perspective. Management Learning, 39, 483-501.

Etzkowitz, H. 1998. The norms of entrepreneurial science: cognitive effects of the new university-industry linkages. Research policy, 27, 823-833.

Farjoun, M. 2010. Beyond Dualism: Stability and Change as a Duality. Academy of Management Review, 35, $202-225$.

Feldman, M. S. \& Orlikowski, W. J. 2011. Theorizing practice and practicing theory. Organization Science, 22, 1240-1253.

Fernández-López, S., Rodríguez-Gulías, M. J., Dios-Vicente, A. \& Rodeiro-Pazos, D. 2020. Individual and joint effect of patenting and exporting on the university spin-offs' survival. Technology in Society, 101326.

Gibbons, M., Limoges, C., Nowotny, H., Schwartzman, S., Scott, P. \& Trow, M. 1994. The New Production of Knowledge: The Dynamics of Science and Research in Contemporary Societies, London, Sage Publications.

Grant, R. M. 1996. Toward a knowledge-based theory of the firm. Strategic management journal, 17, 109-122.

Hallen, B. L., Cohen, S. L. \& Bingham, C. B. 2020. Do Accelerators Work? If So, How? Organization Science.

Hambrick, D. C. 1994. What if the Academy Actually Mattered? Academy of Management Review, 19, 11-16.

Herschel, R. T., Nemati, H. \& Steiger, D. 2001. Tacit to explicit knowledge conversion: knowledge exchange protocols. Journal of Knowledge Management, 5, 107-116.

Hessels, L. K. \& Van Lente, H. 2008. Re-thinking new knowledge production: A literature review and a research agenda. Research Policy, 37, 740-760.

Huff, A. S. 2000. 1999 Presidential Address: Changes in Organizational Knowledge Production. Academy of Management Review, 25, 288-293.

Huff, A. S. \& Huff, J. O. 2001. Re-Focusing the Business School Agenda. British Journal of Management, 12, S49.

Hughes, T. I. M., Bence, D., Grisoni, L., O'regan, N. \& Wornham, D. 2011. Scholarship That Matters: Academic--Practitioner Engagement in Business and Management. Academy of Management Learning \& Education, 10, 40-57.

Kumar, J. A. \& Ganesh, L. S. 2009. Research on knowledge transfer in organizations: a morphology. Journal of Knowledge Management, 13, 161-174.

Lane, P. J., Koka, B. R. \& Pathak, S. 2006. The Reification of Absorptive Capacity: A Critical Review and Rejuvenation of the Construct. Academy of Management Review, 31, 833-863.

Lim, K. 2009. The many faces of absorptive capacity: spillovers of copper interconnect technology for semiconductor chips. Industrial and Corporate Change, 18, 1249-1284.

Mckelvey, B. 2006. Van de Ven and Johnson's "Engaged Scholarship": Nice Try, But. Academy of Management Review, 31, 822-829.

Mcloughlin, D. \& Horan, C. 2000. Business marketing: Perspectives from the markets-as-networks approach. Industrial Marketing Management, 29, 285-292. 
Mcloughlin, D. \& Horan, C. 2002. Markets-as-networks: notes on a unique understanding. Journal of Business Research, 55, 535-543.

Nieto, M. \& Quevedo, P. 2005. Absorptive capacity, technological opportunity, knowledge spillovers, and innovative effort. Technovation, 25, 1141-1157.

Nowotny, H., Scott, P. \& Gibbons, M. 2001. Re-thinking Science: Knowledge and the Public in an Age of Uncertainty, Polity. Oreskes, N. 2019. Why trust science?, Princeton University Press.

Paulin, D. \& Suneson, K. 2012. Knowledge transfer, knowledge sharing and knowledge barriers-three blurry terms in KM. Electronic Journal on Knowledge Management, 10, 81-91.

Perkmann, M., Tartari, V., Mckelvey, M., Autio, E., Broström, A., D’este, P., Fini, R., Geuna, A., Grimaldi, R. \& Hughes, A. 2013. Academic engagement and commercialisation: A review of the literature on university-industry relations. Research policy, 42, 423-442.

Perkmann, M. \& WALSH, K. 2007. University-industry relationships and open innovation: Towards a research agenda. International Journal of Management Reviews, 9, 259-280.

Pettigrew, A. M. 1997. The Double Hurdles for Management Research. Advancement in organizational behaviour: . In: CLARKE, T. (ed.) Advancement in Organisational Behaviour. Essays in honour of Derek S. Pugh. London: Dartmouth Press.

Røvik, K. A. 2016. Knowledge transfer as translation: Review and elements of an instrumental theory. International Journal of Management Reviews, 18, 290-310.

Rynes, S. L., Bartunek, J. M. \& Daft, R. L. 2001. Across the Great Divide: Knowledge Creation and Transfer Between Practitioners and Academics. Academy of Management Journal, 44, 340-355.

Starkey, K. 2001. In Defence of Modes One, Two and Three: A Response. British Journal of Management, 12, S77.

Starkey, K. \& Madan, P. 2001. Bridging the relevance gap: aligning stakeholders in the future of management research. British Journal of Management, 12, S3-S26.

Thijssen, T. 2009. Knowledge Production and Generating Value: Taking the Dual Hurdle of Rigor and Relevance in an Entrepreneurial Way. Real Learning Opportunities at Business School and Beyond. Springer.

Tsoukas, H. 2009. A dialogical approach to the creation of new knowledge in organizations. Organization Science, 20, 941957.

Van De Ven, A. H. 2007. Engaged Scholarship: A Guide for Organizational and Research Knowledge. New York: : Oxford University Press.

Van De Ven, A. H. \& Johnson, P. E. 2006a. Knowledge for Theory and Practice. Academy of Management Review, 31, 802821.

Van De Ven, A. H. \& Johnson, P. E. 2006b. Reply - Nice Try, Bill, But... There You Go Again. Academy of Management Review, 31, 830-832.

Van Den Bulte, C., Lievens, A. \& Moenaert, R. 2001. Market Knowledge, Social Capital and Absorptive Capacity: An Analysis of Knowledge Spillovers within Marketing Departments. INFORMS Marketing Science Conference, Wiesbaden, Germany, July, 5-8.

Von Krogh, G., Nonaka, I. \& Nishiguchi, T. 2000. Knowledge Creation: A Source of Value, Palgrave Macmillan.

Wang, S. \& Noe, R. A. 2010. Knowledge sharing: A review and directions for future research. Human Resource Management Review, 20, 115-131. 